\title{
Physical activity at 36 years: patterns and childhood predictors in a longitudinal study
}

\author{
D J L Kuh, C Cooper
}

\begin{abstract}
Objective-The aim was to describe the sex and socioeconomic differences in patterns of physical activity at work and in leisure time of men and women aged 36 years, and to investigate factors in childhood and adolescence which predict high rates of participation in sports and recreational activities in later life.

Design-Data collected in childhood, adolescence, and at 36 years on members of a national prospective birth cohort study were used.
\end{abstract}

Setting-The population sample was resident in England, Scotland, and Wales.

Subjects-A stratified sample of about 3500 men and women was studied regularly from birth until 43 years.

Measurements and main results-More men than women reported high rates of sports and recreational activities, gardening, and do-it-yourself. In contrast women reported higher rates of bicycling and walking. Higher levels of education were associated with frequent participation in sports. Individuals often engaged in one type of activity without necessarily engaging in other types. Those who were most active in sport had been above average at sports in school, more outgoing socially in adolescence, had fewer health problems in childhood, were better educated, and had more mothers with a secondary education than those who were less active.

Conclusions-Studies that examine the relationship between physical activity and chronic disease should consider a broad range of pursuits rather than extrapolating from only one area of physical activity, and in their explanations should take account of the possible role of childhood characteristics. The findings suggest the importance of developing skills and habits in childhood as well as of encouraging healthier exercise habits in adults who may have had few opportunities or low motivation previously.

The importance of physical activity for individual health and wellbeing has been recognised for 2000 years. ${ }^{12}$ The lack of physical fitness in the British population has been seen as a problem throughout this century and the need for physical training was stressed by a number of major public health reports. $^{3-5}$ The promotion of physical activity in the general population gathered momentum with the passing of the Physical Training and Recreation Act in $1937^{6}$ which increased government financial support to local authorities for the development of public sports and recreational activities. The setting up of the advisory Sports Council in 1965 (which became the independent Sports Council in 1972) was an indication that sport and physical recreation were considered to be self justified and did not need the support of a drive to national fitness. ${ }^{7}$

Physical activity "is not a single entity; there are many kinds of activity which vary in intensity, frequency and duration, and which have variable effects on body systems". 8 Physical capacities may be broadly divided into muscle strength and stamina. These two attributes are distinct, and differently trained. Muscle strength depends on contractile proteins within muscle cells, and changes in strength throughout life are thought to be mediated through muscle cell hypertrophy rather than increased cell number. Stamina (endurance capacity, aerobic capacity, maximal oxygen uptake) is required for rhythmic exercise such as walking, swimming, or cycling. In addition to muscle strength, stamina requires a good capacity for oxygen delivery in the cardiovascular system, and a good capacity for work uptake in muscle cells.

Epidemiological research has attempted to associate inactivity with several diseases, most notably ischaemic heart disease and osteoporosis. While vigorous exercise, requiring high endurance capacity, appears to be associated with low coronary risk, ${ }^{9-14}$ muscle loading activity seems more important to the maintenance of skeletal integrity in later life. ${ }^{15}$

The generation of preventive strategies incorporating exercise for these public health problems requires greater knowledge of the kinds of activity currently undertaken by members of the general population, and an understanding of its determininants. Such information is scarce. We have therefore examined activity patterns in work and leisure in a national sample of over 3300 men and women aged 36 years who are members of the 1946 national birth cohort study. The longitudinal nature of these data enables us to investigate childhood influences on adult activity patterns.

\section{Methods}

The MRC National Survey of Health and Development is a social class stratified sample of the single legitimate births that occurred in the week 3-9 March 1946 in England, Wales, and Scotland. There were 10 follow up contacts in infancy and childhood and nine contacts so far in adult life, up to the age of 43 years. Losses have occurred at population appropriate rates through 
death and emigration, and at the last contact $89 \%$ of the resident target population were interviewed and measured. Summaries of the survey are given by Atkins et al ${ }^{16}$ and Wadsworth. ${ }^{17}$ Adjustments for sample stratification have been made where necessary.

In 1982 when cohort members were 36 years old, information on the frequency and duration of a range of active leisure pursuits in the preceding month was collected by trained nurse interviewers during a home visit. The questionnaire was based on the Minnesota leisure time physical activity questionnaire. ${ }^{18}$ From this information three main areas of active leisure pursuits were defined: sports and recreational activities, cycling and walking, and heavy gardening and do-it-yourself (DIY) activities. The questionnaire schedule also included questions on the amount of sitting, walking, and heavy lifting during the working day. They were based on the questions used by Shapiro et al, adapted to include survey members who were not in paid work. ${ }^{19}$

For each area people were classified according to the criteria in table I, either into a most active group, a less active group, or an inactive group. This simple classification system was chosen instead of estimating units of energy expended in various activities from reported duration times using standard intensity codes. ${ }^{18}$ There was a wide variation in reported duration of particular activities and, we suspected, a wide variation in intensity. The use of energy units ( $\mathrm{kcal}, \mathrm{kJ})$ would have given a false sense of accuracy, and data on physical activity at work could not have been derived in a similar manner.

Survey members were asked how many times in the last month they had done anything at work, in the home, or during their spare time that had made them out of breath. Their responses [grouped into five or more $(8 \%)$, one to four

Table I Criteria used to classify physical activity

\begin{tabular}{|c|c|c|c|}
\hline Type of physical activity & Most active & Less active & Inactive \\
\hline $\begin{array}{l}\text { Physical activity during the } \\
\text { working day }\end{array}$ & $\begin{array}{l}\text { Either } \\
\text { (i) over half the } \\
\text { day spent } \\
\text { walking } \\
\text { or } \\
\text { (ii) frequently } \\
\text { lifts and carries } \\
\text { heavy things }\end{array}$ & $\begin{array}{l}\text { Not classified in } \\
\text { the most active } \\
\text { or inactive } \\
\text { groups }\end{array}$ & $\begin{array}{l}\text { At least half the day } \\
\text { sitting down }\end{array}$ \\
\hline $\begin{array}{l}\text { Sports and recreational } \\
\text { activities: } \\
\text { List of } 27 \text { activities (eg, } \\
\text { badminton, swimming, } \\
\text { yoga, exercises such as press } \\
\text { ups at home, dancing, } \\
\text { football, jogging, etc) }\end{array}$ & $\begin{array}{l}\text { Five of more } \\
\text { times in the } \\
\text { previous month }\end{array}$ & $\begin{array}{l}1-4 \text { times in } \\
\text { previous month }\end{array}$ & $\begin{array}{l}\text { No reported activity in } \\
\text { previous month }\end{array}$ \\
\hline
\end{tabular}

\begin{tabular}{llll}
\hline Cycling and walking & $\begin{array}{l}\text { Either } \\
\text { (i) normally } \\
\text { rides or walks to } \\
\text { work for at least } \\
\frac{1}{2} \text { hour (round } \\
\text { trip) } \\
\text { or } \\
\text { (ii) 12 rides or } \\
\begin{array}{l}\text { walks of } \frac{1}{2} \text { hour } \\
\text { in leisure time in } \\
\text { previous month }\end{array}\end{array}$ & $\begin{array}{l}\text { Either } \\
\text { (i) normally } \\
\text { rider less than } \frac{1}{2} \\
\text { hour } \\
\text { or } \\
\text { (ii) 1-11 rides or } \\
\text { walks of } \frac{1}{2} \text { hour } \\
\text { previous month }\end{array}$ & $\begin{array}{l}\text { Does not normally ride } \\
\text { or walk and no reports } \\
\text { of riding or walking in } \\
\text { leisure time in previous } \\
\text { month }\end{array}$ \\
& & & \\
\hline $\begin{array}{l}\text { Heavy gardening and DIY: } \\
\text { List of 10 heavy activities } \\
\text { (eg, digging earth, chopping } \\
\text { wood, brick laying, moving } \\
\text { heavy objects, etc) }\end{array}$ & $\begin{array}{l}\text { Five or more } \\
\text { times in the } \\
\text { previous month }\end{array}$ & $\begin{array}{l}1-4 \text { times in } \\
\text { previous month }\end{array}$ & $\begin{array}{l}\text { No reported activity in } \\
\text { previous month }\end{array}$ \\
\hline
\end{tabular}

$(10 \%)$, or no reports $(82 \%)$ of being out of breath] were used as an indirect check of the validity of the activity levels in terms of strenuous activity.

Ninety per cent of the interviews were conducted between April and September. Seasonal influences on the frequency of active leisure pursuits were investigated.

Own adult social class (at 36 years) and father's social class when the cohort member was four years old were assigned according to the classification used in the 1970 census. ${ }^{20}$ The highest qualification achieved by cohort members by age 26 years was classified on the Burnham scale, ${ }^{21}$ and was grouped into five levels: no qualifications, less than " $O$ " level, " $O$ " level and equivalents, " $A$ " level and equivalents, and degree level and equivalents. The classification of parental education not only distinguished parents whose education had stopped at primary, secondary, or tertiary level but also took account of those who had not attended secondary school but who went back in later years for further education.

In 1959, when cohort members were 13 years old, teachers were asked to rate cohort members' ability in sports as above average, below average, or average compared with their age peers.

At 15 years teachers assessed children's energy levels as extremely energetic and never tired, normally energetic, or always tired and washed out. The survey children's questionnaire at age 13 years included the Pintner aspects of personality inventory ${ }^{22} 23$ which provided the extrovertintrovert scale used in these analyses. The scale provides a score from 0 (introvert) to 15 (extrovert) and a high score reflects a high degree of sociability. For example, extroverts were those who said they made friends easily, preferred friends to books, found it easy to start speaking to a new pupil, and liked asking questions in class.

Serious illness in childhood (up to 15 years) was defined as any condition which necessitated hospital admission of a minimum of 28 days, or school absence of three consecutive weeks. At the medical examination when cohort members were 13 years old a doctor identified those who had physical disabilities that were likely to interfere with participation in school activities. For simplification in the multivariate analyses these two measures were collapsed into a single dichotomous variable.

Multivariate analyses were undertaken using the stepwise logistic regression model in the BMDP statistical package and interactions in the final model were investigated.

\section{Results}

PATTERNS OF PHYSICAL ACTIVITY

Sixty six per cent of men and $56 \%$ of women reported participating in sports and recreational activities in the preceding month (ie, those in the most and less active categories in table II). This may overestimate average levels of activity over a year as there were significant seasonal fluctuations in the frequency of reported activities, and $90 \%$ of the interviews were conducted between April and September. Table III shows the most frequently performed activities. Swimming was reported by $24 \%$ of subjects, and "exercise like press ups at 
Table II Activity levels for men and women by type of activity ( $n=3322$ )

\begin{tabular}{|c|c|c|c|c|c|c|c|c|}
\hline & \multicolumn{8}{|c|}{ Activity level } \\
\hline & $\begin{array}{l}\text { Most } \\
M \\
\left({ }^{o} o\right)\end{array}$ & $\begin{array}{l}\text { tive } \\
F \\
\left(\begin{array}{c}o \\
o\end{array}\right)\end{array}$ & $\begin{array}{l}\text { Less } \\
M \\
\left({ }_{0}{ }_{0}\right)\end{array}$ & $\begin{array}{l}\text { ive } \\
F \\
\left({ }^{o}{ }_{0}\right)\end{array}$ & $\begin{array}{l}\text { Inactive } \\
M \\
\left({ }^{\circ}{ }_{0}\right)\end{array}$ & $\begin{array}{l}F \\
\left(o_{0}\right)\end{array}$ & $\begin{array}{l}\text { Not } \\
M \\
\left(o_{o}\right)\end{array}$ & $\begin{array}{c}o w n \\
F \\
\left({ }^{o}{ }_{0}\right)\end{array}$ \\
\hline $\begin{array}{l}\text { Workplace activity } \\
\text { Sports/recreational } \\
\text { Cycling/walking } \\
\text { Heavy gardening/DIY }\end{array}$ & $\begin{array}{l}51 \cdot 6 \\
41 \cdot 2 \\
27 \cdot 9 \\
29 \cdot 1\end{array}$ & $\begin{array}{l}60 \cdot 8 \\
31 \cdot 2 \\
36 \cdot 0 \\
11 \cdot 9\end{array}$ & $\begin{array}{r}8 \cdot 9 \\
25 \cdot 1 \\
46 \cdot 2 \\
35 \cdot 1\end{array}$ & $\begin{array}{l}12 \cdot 5 \\
25 \cdot 1 \\
42 \cdot 6 \\
31 \cdot 7\end{array}$ & $\begin{array}{l}38 \cdot 3 \\
33 \cdot 1 \\
24 \cdot 8 \\
35 \cdot 1\end{array}$ & $\begin{array}{l}25 \cdot 7 \\
43 \cdot 5 \\
21 \cdot 0 \\
56 \cdot 2\end{array}$ & $\begin{array}{l}1 \cdot 1 \\
0 \cdot 6 \\
1 \cdot 0 \\
0 \cdot 7\end{array}$ & $\begin{array}{l}1 \cdot 1 \\
0 \cdot 2 \\
0 \cdot 3 \\
0 \cdot 1\end{array}$ \\
\hline
\end{tabular}

home" by $17 \%$. Swimming and golf were more frequently reported by those interviewed in the summer months. Figure 1 shows that the proportion of men and women in the most active category increased significantly $(p<0.001)$ with educational qualifications.

Men were more likely than women to report heavy gardening activities in the previous month. Cycling and walking, in contrast, were reported more frequently by women than men (table II). Both types of activity showed significant seasonal fluctuation. In neither area was membership of the most active group significantly associated with educational qualifications. Differences in educational attainment were only apparent between the inactive and less active groups; compared with those with few or no educational qualifications better educated men and women were more likely to report some cycling or walking rather than none, and better educated women were more likely to report some heavy gardening and DIY rather than none.

Figure 2 shows the overlap between sports, walking/cycling, and gardening/DIY in individuals. Only $5 \%$ of men and $3 \%$ of women were classified in the most active category for all three groups; most of the subjects were in only one of these groups. Just under a third of men $(32 \%)$ and two fifths of women $(42 \%)$ were in the less active or inactive categories for all three activity types.

Table III Sports and recreational activities in the previous month reported by at least one in 10 men and women at 36 years

\begin{tabular}{lrlr}
\hline & $\begin{array}{c}\text { Men } \\
\left(o_{0}\right)\end{array}$ & $\begin{array}{c}\text { Women } \\
\left(\sigma_{0}\right)\end{array}$ \\
\hline Swimming & 23.3 & Swimming & $24 \cdot 7$ \\
Exercises at home & 16.0 & Exercises at home & 18.2 \\
Golf & 11.6 & Dancing & 15.4 \\
Jogging & 11.1 & Movement to music & 9.5 \\
Squash & 10.9 & & \\
Dancing & 10.0 & & \\
Football & 9.8 & &
\end{tabular}

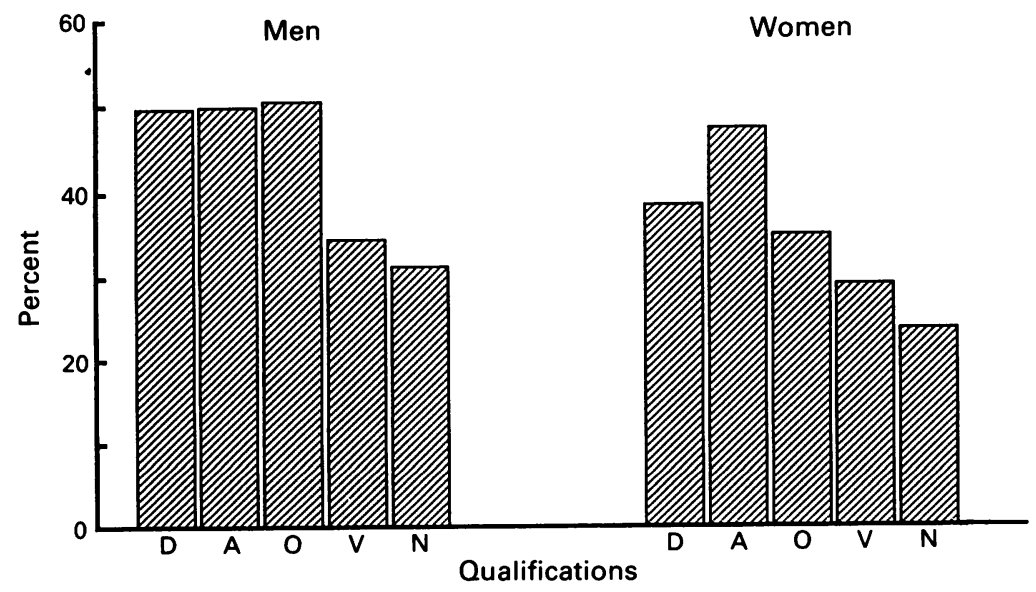

$D=$ Degree; $A=$ " $A$ " level; $O=$ "O" level; $V=$ Vocational; $N=$ None

Figure 1 Percentage reporting sports activities at least five times in previous month
Fifty two per cent of men and $61{ }_{\circ}^{\circ}$ of women in the sample were categorised in the most physically active group at work (defined as either walking for over half the day or frequently lifting and carrying heavy loads). Those in the manual social classes were significantly more active at work than those in the non-manual classes (see fig 3; $p<0.001$ ). Women did less lifting and carrying than men, and were more likely to be classified as active on the basis of walking. Women in social classes 1 and 2 were more active than their male counterparts.

There was some evidence that men, but not women, in sedentary occupations compensated by being more active in their leisure time: $71^{\circ}{ }_{0}$ of men who were inactive at work were classified into at least one of the most active leisure groups compared with $62^{\circ} \%$ of men reporting high levels of activity at work $(p<0.001)$.

Overall $13 \%$ of men and $17^{\circ}$ of women did not achieve membership of a most active group, either at work or in their leisure time.

EARLY PREDICTORS OF ADULT PARTICIPATION IN SPORTS

There was evidence from this study that measures of socioeconomic status of the family of origin and certain childhood attributes were associated with participation in sporting activity of men and women in later life (table IV). Parental education was a significant $(p<0.01)$ predictor of those in the most active sports category at 36 years. Paternal social class showed a similar trend in both sexes, but the relationship only attained significance in women. Multiple logistic regression showed that although these variables were highly interrelated, they each contributed a significant independent effect. When account was also taken of cohort members' own educational qualifications, the effects of fathers' social class and educational level became insignificant as those from poor family backgrounds who rose up the educational ladder took on the same level of sports participation as other well educated people from more favoured backgrounds.

Adolescent characteristics which were positive predictors of high sporting activity at age 36 years included above average ability at school games, high energy level (table IV), and an extrovert personality. The mean scores on the Pintner extrovert scale for men and women in the most active sports category were $9 \cdot 1$ and 8.6 respectively, and were significantly higher than the mean scores for other men and women $(8.6$ and 8.3$)(\mathrm{p}<0.01)$.

Negative predictors of high sporting activity in later life included physical disability and, for women only, serious illness in childhood or adolescence (table IV).

The childhood variables (except for fathers' social class and level of education which had already been found to be mediated by the survey members' own educational qualifications) were examined in a multiple logistic regression model. They all retained statistically significant independent effects on adult participation in sports (table V).

VALIDITY

The validity of the various measures of physical activity adopted in this study was difficult to 
estimate within the framework of the data set itself. We were able, however, to explore the relationship between the levels of various activities and the reported prevalence of breathlessness during the previous month. All of the leisure activities inquired about showed statistically significant $(p<0.001)$ associations with this variable. Using the whole sample, those reporting frequent heavy lifting at work were no more likely to report having been out of breath. However, a significant association $(p<0.01)$ was revealed when the sample was restricted to those who were inactive or less active in leisure activities, suggesting that the previous lack of association had been due to higher activity levels of sedentary workers in their leisure time.
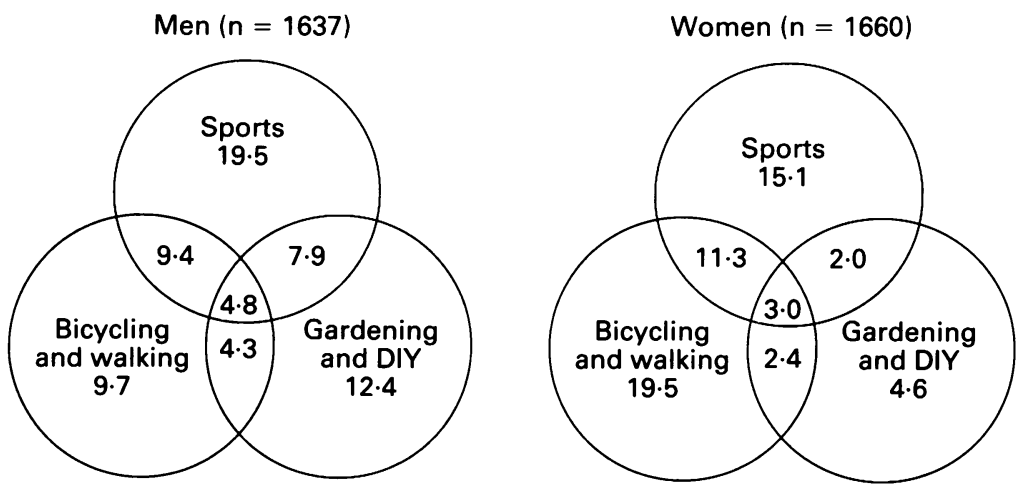

Not highly active in any activity: $32.0 \%$ (men); $42.2 \%$ (women)

Figure 2 Percentage highly active in at least one type of leisure activity
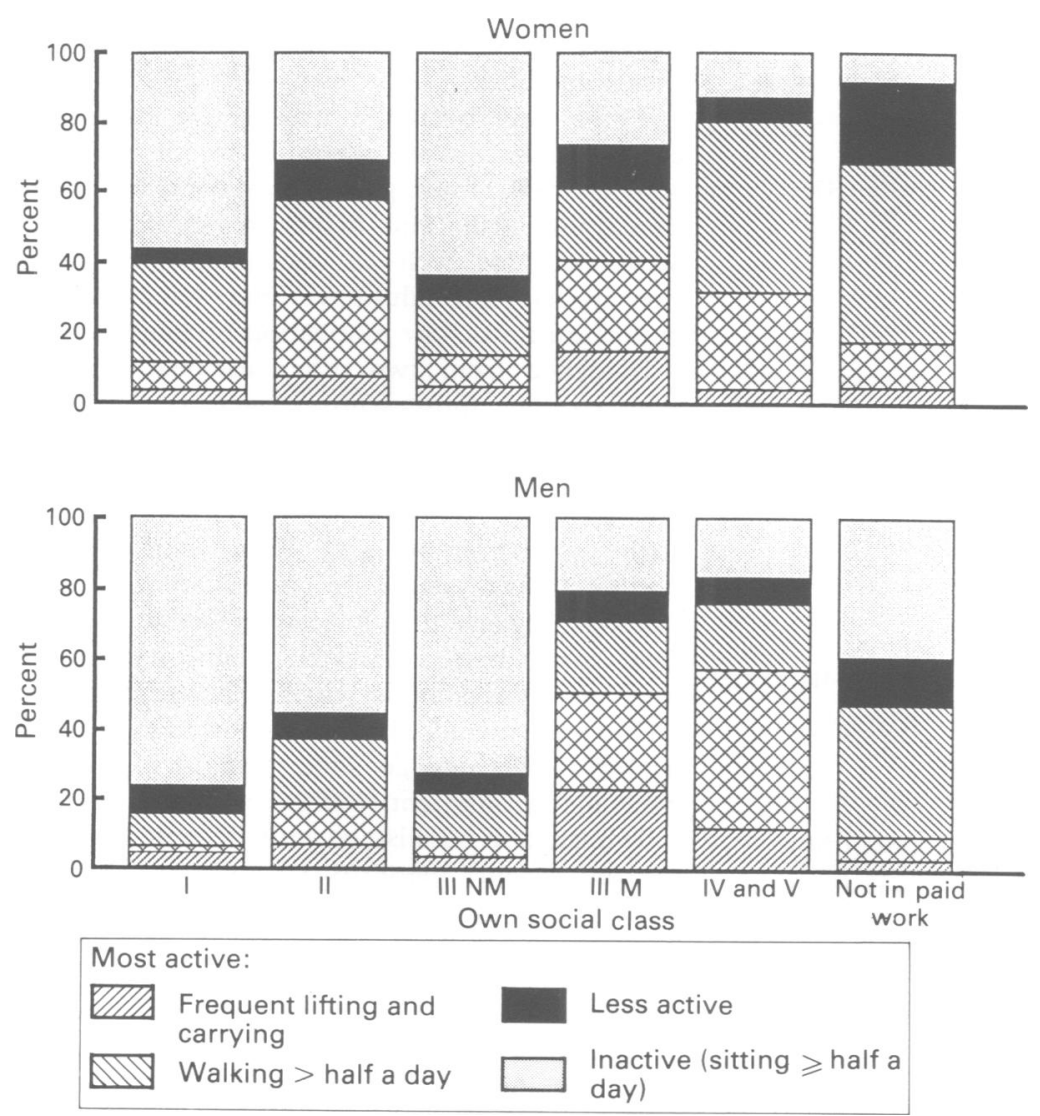

Figure 3 Physical activity during working day according to own social class
Discussion

This study provides data on the activity patterns of a national sample of people aged 36 years. When categorised into occupational and leisure components, there was little concordance within individuals on the level of activity in each component. Sex, social class, and previous educational attainment appear to have differential but statistically significant effects on activity in the work place and at leisure. Several childhood attributes, most notably ability at games, extrovert personality, serious illness, and educational attainment, exerted independent additional effects on sports and recreational activities at age 36 years.

Many epidemiological studies have sought an association between activity level and disease. Activity assessment in such studies constitutes a major methodological problem. The four major methods which have been evaluated are a structured questionnaire, diary recording, body born instruments such as an electrocardiograph, and measurement of energy intake. Only the questionnaire and diary methods are capable of providing information on the wide range of occupational and leisure activities which constitute total physical activity. They are, however, prone to bias in recall, as well as to variation in validity. The sample adopted in our study was large and representative of the 36 year old population of this country. The response rate was high, and careful descriptions of a wide range of activities which constitute total physical activity were sought. It thus seems unlikely that reporting bias could explain the observed relationships between activity and sex, social status, and educational level.

The validity of activity recall constitutes a greater problem. Investigators are faced with a wide array of questionnaires of varying complexity, length, and time frame. Ascertainment of information on leisure activity in our survey was based upon the Minnesota leisure time physical activity questionnaire. ${ }^{18}$ In a recent study, ${ }^{24}$ this questionnaire correlated well with treadmill estimation of oxygen uptake and body composition, two traditional gold standards for physical activity measurement. A poor relationship was found, however, between the questionnaire and occupational activity. Yet, occupational activity is clearly relevant to disease aetiology under certain circumstances, as evidenced by the recently reported association between occupation in middle life and subsequent risk of hip fracture. ${ }^{25}$ Perhaps of greater interest, most of the nine other activity questionnaires included in the validation study described above ${ }^{24}$ performed in a similar manner. Such data support the notion that there are many separate dimensions of physical activity each requiring their own method of validation. Perhaps the length and attention to detail of any questionnaire are less important than the logic of its questions in the context of the disease being studied.

Our observation that those who were active at work engaged in less leisure activity, and that individuals often engaged in one type of leisure activity without necessarily becoming involved in other types, suggests that future studies should take account of a broad range of pursuits rather 
Table IV Early life predictors of participation in sports and recreational activities at 36 years

\begin{tabular}{|c|c|c|c|c|}
\hline & \multicolumn{2}{|l|}{ Men } & \multicolumn{2}{|c|}{ Women } \\
\hline & $n$ & $\begin{array}{l}\% \text { in most } \\
\text { active group }\end{array}$ & $n$ & $\begin{array}{l}\% \text { in most } \\
\text { active group }\end{array}$ \\
\hline $\begin{array}{l}\text { Father's education } \\
\text { Secondary }+\mathrm{FE} \text { or higher } \\
\text { Secondary only } \\
\text { Primary }+\mathrm{FE}^{\mathrm{b}} \\
\text { Primary only }\end{array}$ & $\begin{array}{l}215 \\
202 \\
213 \\
792\end{array}$ & $\begin{array}{l}51 \cdot 6 \\
45 \cdot 0 \\
42 \cdot 3 \\
39 \cdot 6 \\
\star \star\end{array}$ & $\begin{array}{l}223 \\
197 \\
182 \\
848\end{array}$ & $\begin{array}{l}48 \cdot 0 \\
40 \cdot 1 \\
41 \cdot 8 \\
26 \cdot 7 \\
\star \star \star\end{array}$ \\
\hline $\begin{array}{l}\text { Mother's education } \\
\text { Secondary }+ \text { FE or higher } \\
\text { Secondary only } \\
\text { Primary + FE }{ }^{\mathrm{a}} \\
\text { Primary only }\end{array}$ & $\begin{array}{l}163 \\
172 \\
227 \\
878\end{array}$ & $\begin{array}{l}40 \cdot 5 \\
57 \cdot 0 \\
47 \cdot 6 \\
38 \cdot 5 \\
\star \star \star\end{array}$ & $\begin{array}{l}172 \\
152 \\
199 \\
937\end{array}$ & $\begin{array}{l}47 \cdot 7 \\
40 \cdot 1 \\
37 \cdot 2 \\
28 \cdot 7 \\
\star \star \star\end{array}$ \\
\hline $\begin{array}{l}\text { Father's social class } \\
\text { I and II } \\
\text { III non-manual } \\
\text { III manual } \\
\text { IV and V }\end{array}$ & $\begin{array}{l}333 \\
274 \\
456 \\
420\end{array}$ & $\begin{array}{l}46 \cdot 5 \\
44 \cdot 5 \\
42 \cdot 3 \\
37 \cdot 4\end{array}$ & $\begin{array}{l}335 \\
282 \\
465 \\
412\end{array}$ & $\begin{array}{l}45 \cdot 7 \\
40 \cdot 9 \\
30 \cdot 1 \\
24 \cdot 3 \\
\star \star \star\end{array}$ \\
\hline $\begin{array}{l}\text { Ability at games } 13 \text { years } \\
\text { Above average } \\
\text { Average } \\
\text { Below average }\end{array}$ & $\begin{array}{l}326 \\
873 \\
237\end{array}$ & $\begin{array}{l}54 \cdot 0 \\
41 \cdot 2 \\
34 \cdot 6 \\
\star \star \star\end{array}$ & $\begin{array}{l}249 \\
959 \\
179\end{array}$ & $\begin{array}{l}41 \cdot 8 \\
33 \cdot 5 \\
21 \cdot 8 \\
\star \star \star\end{array}$ \\
\hline $\begin{array}{l}\text { Energy level at } 13 \text { years } \\
\text { Extremely energetic } \\
\text { Normally energetic } \\
\text { Always tired and washed out }\end{array}$ & $\begin{array}{r}91 \\
1307 \\
75\end{array}$ & $\begin{array}{l}53 \cdot 8 \\
42 \cdot 7 \\
34 \cdot 7 \\
\star\end{array}$ & $\begin{array}{r}91 \\
1179 \\
111\end{array}$ & $\begin{array}{l}56 \cdot 0 \\
31 \cdot 8 \\
25 \cdot 2 \\
\star \star \star\end{array}$ \\
\hline $\begin{array}{l}\text { Physical disability at } 13 \text { years } \\
\text { No } \\
\text { Yes }\end{array}$ & $\begin{array}{r}1331 \\
77\end{array}$ & $\begin{array}{l}43 \cdot 5 \\
27 \cdot 3 \\
\star \star\end{array}$ & $\begin{array}{r}1342 \\
79\end{array}$ & $\begin{array}{l}34 \cdot 1 \\
20 \cdot 3 \\
\star \star\end{array}$ \\
\hline $\begin{array}{l}\text { Serious illness (0-15 years) } \\
\text { No } \\
\text { Yes }\end{array}$ & $\begin{array}{r}1272 \\
333\end{array}$ & $\begin{array}{l}42 \cdot 7 \\
39 \cdot 9\end{array}$ & $\begin{array}{r}1345 \\
280\end{array}$ & $\begin{array}{l}35 \cdot 1 \\
26 \cdot 1 \\
\star \star\end{array}$ \\
\hline
\end{tabular}

$\mathrm{FE}=$ Further education

a Or primary and FE or higher

$\mathrm{b}$ Includes those who attended $\mathrm{FE}$ courses but did not obtain any recognised qualifications $\star_{\star \star \star} \mathrm{p}<0.001 ;{ }^{\star \star} \mathrm{p}>0.001<0.01 ;{ }^{\star} \mathrm{p}>0.01<0.05$

Table $V$ Early life predictors of a high level of participation in sports and recreational activities at 36 years $(n=2144)$

\begin{tabular}{|c|c|c|c|}
\hline & $n$ & Odds ratio & $\begin{array}{l}(95 \% \text { confidence } \\
\text { intervals) }\end{array}$ \\
\hline $\begin{array}{l}\text { Educational qualifications } \\
\text { None } \\
\text { Vocational } \\
\text { "O" level or equivalent } \\
\text { "A" level or equivalent } \\
\text { Degree level or equivalent }\end{array}$ & $\begin{array}{l}(805) \\
(163) \\
(445) \\
(537) \\
(194)\end{array}$ & $\begin{array}{l}1 \cdot 00 \\
1 \cdot 10 \\
1 \cdot 74 \\
2 \cdot 16 \\
1 \cdot 67 \\
\star \star \star\end{array}$ & $\begin{array}{l}(0 \cdot 82-1 \cdot 47) \\
(1 \cdot 44-2 \cdot 10) \\
(1 \cdot 82-2 \cdot 58) \\
(1 \cdot 28-2 \cdot 18)\end{array}$ \\
\hline Extraversion & & $1 \cdot 19^{a}$ & \\
\hline $\begin{array}{l}\text { Sex } \\
\text { Male } \\
\text { Female }\end{array}$ & $\begin{array}{l}(1066) \\
(1078)\end{array}$ & $\begin{array}{l}1.00 \\
0.63 \\
\star \star \star\end{array}$ & $(0.58-0.70)$ \\
\hline $\begin{array}{l}\text { Ability at games at } 13 \text { years } \\
\text { Below average } \\
\text { Average } \\
\text { Above average }\end{array}$ & $\begin{array}{r}(311) \\
(1427) \\
(406)\end{array}$ & $\begin{array}{l}0.72 \\
1.00 \\
1.35 \\
\star \star \star\end{array}$ & $\begin{array}{l}(0 \cdot 60-0 \cdot 87) \\
(1 \cdot 14-1 \cdot 59)\end{array}$ \\
\hline $\begin{array}{l}\text { Energy levels at } 13 \text { years } \\
\text { Always tired and washed out } \\
\text { Normally energetic } \\
\text { Extremely energetic, never tired }\end{array}$ & $\begin{array}{r}(104) \\
(1860) \\
(144)\end{array}$ & $\begin{array}{l}0.94 \\
1.00 \\
1.62 \\
\star\end{array}$ & $\begin{array}{l}(0 \cdot 80-1 \cdot 41) \\
(1 \cdot 24-2 \cdot 11)\end{array}$ \\
\hline $\begin{array}{l}\text { Mother's education } \\
\text { Primary only } \\
\text { Primary + FE } \\
\text { Secondary only } \\
\text { Secondary + FE of higher }\end{array}$ & $\begin{array}{r}(1357) \\
(330) \\
(221) \\
(236)\end{array}$ & $\begin{array}{l}1 \cdot 00 \\
1 \cdot 24 \\
1 \cdot 52 \\
1 \cdot 24 \\
\star\end{array}$ & $\begin{array}{l}(1.02-1.50) \\
(1.22-1.91) \\
(0.99-1.55)\end{array}$ \\
\hline $\begin{array}{l}\text { Childhood ill health } \\
\text { Serious illness or physical } \\
\text { disability } \\
\text { None }\end{array}$ & $\begin{array}{r}(477) \\
(1667)\end{array}$ & $\begin{array}{l}0.79 \\
1.00 \\
\star\end{array}$ & $(0.71-0.89)$ \\
\hline
\end{tabular}

FE = further education

Goodness of fit $\chi^{2} 0 \cdot 143$

based on 1 SD change

$\star \star \star p<0.001 ;{ }^{\star} p>0.01<0.05$ than extrapolating from a brief description of occupation 2627 or a short series of questions on leisure time pursuits. Such methodological failings may partly explain the weaker associations between exercise and disease in studies using questionnaire based methodology when compared with those using physiological measurements of aerobic capacity. ${ }^{28}$

For health benefits to accrue physical activity must be maintained. Lifestyles which involve walking, cycling, and gardening may be easier to maintain in the long run than participation in sports, which tends to decrease rapidly with age. Those who get most of their exercise from sports or from work tasks will have to make lifestyle changes as they age and retire in order to maintain exercise levels.

The study revealed a number of ways by which those who took part in sports were a selected group compared with the less active. They had fewer childhood health problems, had been assessed as outgoing socially in adolescence, were more likely to have been above average at school games, to have been well educated and have mothers with a secondary education. Many of these childhood factors have also been found to be associated with various aspects of health. ${ }^{29-31}$ Cross sectional studies and adult follow up studies should take this problem of selection into account when examining the relationship between sports activities and mental or physical health.

The importance of the level of mothers' education to participation in sports activities by their adult offspring may reflect greater exposure to opportunities for sport for mothers who went to secondary school compared to their peers who left after a primary education and went earlier into the world of work. This study did not obtain information about the parents' participation in sports activities.

There have been few prospective studies of early influences on adult levels of physical activity. ${ }^{32}$ Our findings suggest the importance of developing skills and habits in childhood and adolescence as well as encouraging healthier exercise habits in adults who may have had few opportunities or low motivation previously.

Evidence from two other national samples suggests that those who frequently engage in sports and recreational activities are better educated $^{33}$ or have non-manual occupations. ${ }^{34}$ The relationship between other leisure activities, such as gardening and DIY, and current socioeconomic status is inconsistent. ${ }^{33}$ Our findings suggest that for leisure pursuits other than sports better educated people were more likely to report some activities rather than none at all but were no more likely to report high levels of activity; this may go some way to explaining previous inconsistent results.

Information has also recently become available on the activity patterns of children and the elderly. In British school children, ${ }^{35}$ a major concern exists that maintenance of exercise through school games classes is not seen as a priority. A population based study of elderly people in Nottingham ${ }^{36}$ also points towards generally low levels of activity, even in those without significant disabilities. The major components of activity in this study were outdoor 
walking, home activities such as cleaning, washing, and gardening, and muscle loading activities, such as stair climbing. Participation in sport was found to be very infrequent in the elderly. Our results complement these descriptive studies and suggest that a different activity pattern needs to be assessed during the working years of adult life.

There is evidence to implicate physical inactivity in the aetiology of several chronic diseases, most notably osteoporosis and ischaemic heart disease. The design of effective public health strategies requires baseline information on the wide spectrum of physical activity undertaken by men and women at different stages throughout life. This study provides nationally representative normative data on the pattern of, and early influences on, physical activity of adults in early middle age. Activity patterns differ between men and women, and between the workplace and leisure time. They are influenced by current socioeconomic status, as well as by a number of childhood factors. These observations provide a firm basis for future analytical investigations to test the association between inactivity and chronic disease.

The authors would like to thank Dr Mike Wadsworth, Dr Bryan Rodgers, and Miss Susan Mann for their helpful comments on drafts of this paper.

1 Jones WHS. Translation of $A$ regimen for health. In Hippocrates. (Vol IV.) Loeb edition, 1931.

2 Green RM. A translation of Galen's Hygiene (de Sanitate Tuenda). Springfield, Illinois: Charles C Thomas, 1951.

3 Great Britain Parliamentary Papers. Report of the Royal Commission on Physical Training Scotland, vol I: report and appendix Cmnd. 1507; vol II: Minutes of evidence Cmnd. 1508. London: HMSO, 1903.

4 Great Britain Parliamentary Papers. Report of the Interdepartmental Committee on Physical Deterioration. Vol I: report and appendix Cmnd. 2175; Voll II: List of witness and minutes of evidence, Cmnd. 2210; Vol III: appendix and general Index, Cmnd. 2186. London: HMSO, 1904.
British Medical Association. Report of the Physical Education Committee. London: BMA: April, 1934

6 Great Britain Parliamentary Papers. Training and Recreation Act. Cmnd. 5364. London: HMSO, 1937.

7 McIntosh PC. Physical education in England since 1800 Revised and enlarged edition. London: G Bell and Sons, 1968 .

8 Bassey EJ. Benefits of exercise in the elderly. In: Isaacs B, ed. Recent advances in geriatric medicine No 3. Edinburgh Churchill Livingstone, 1985 .

9 Paffenbarger RS, Hale WE. Work activity and coronary heart mortality. $N$ Eng $\mathcal{f}$ Med 1975; 292: 545-9.

10 Morris JN, Heady JA. Mortality in relation to the physical activity of work. $\mathrm{Br} \mathcal{F}$ Ind Med 1953; 10: 245-54.

11 Paffenbarger RS, Wing AL, Hyde R. Physical activity as an index of heart attack risk in college alumni. $A m \mathcal{F}$ Epidemiol 1978 ; 108: $161-75$
12 Paffenbarger RS, Hyde RT, Wing AL, Chung-Cheng Hsieh. Physical activity, all-cause mortality and longevity of college alumni. $N$ Engl f Med 1986; 314; 605-13.

13 Morris JN, Everitt MG, Pollard R, Chave SPW. Vigorous exercise in leisure-time: protection against coronary heart disease. Lancet 1980; ii: 1207-10.

14 Powell KE, Thompson PD, Casperson CJ, Kendrick JS Physical activity and the incidence of coronary heart disease. Annu Rev Public Health 1987; 8: 253-87.

15 Cooper C. Bone mass, muscle function and fracture of the proximal femur. Br $\mathcal{F}$ Hosp Med 1989; 42: 277-80.

16 Atkins E, Cherry N, Douglas JWB, Kiernan KE Wadsworth MEJ. The 1946 British birth cohort: an account of the origins, progress and results of the Nationa Survey of Health and Development. In: Mednick SA, Baer AE, eds. Prospective longitudinal research: an empirical basis for the primary prevention of psychosocial disorders. Oxford: Oxford University Press, 1981: 25.

17 Wadsworth MEJ. Follow-up of the first British national birth cohort: findings from the MRC National Survey of birth cohort: findings from the MRC National Survey of 1: $95-117$.

18 Taylor HL, Jacobs DK, Schucker B, Knudsen J, Leon AS, Debacker $G$. A questionnaire for the assessment of leisur time physical activities. F Chron Dis 1978; 31: 741-55.

19 Shapiro S, Weinblatt E, Frank EW, Sager RV. The H.I.P. study of incidence and prognosis of coronary heart disease. f Chron Dis 1965; 18: 527-58.

20 Office of Population Censuses and Surveys. Classification of occupations. London: HMSO, 1970.

21 Department of Education and Science. Burnham Further Education Committee grading courses 1972. London: HMSO, 1972.

22 Pinter R, Loftus JJ, Forlano G, Alster B. Aspects of personality inventory: test and manual. Yonkers: World Book Company, 1937.

23 Pinter R, Forlano G. Four retests of a personality inventory. f Educ Psychol 1938; 29: 93-100.

24 Jacobs DR, Ainsworth BE, Hartman TJ, Leon AS. A simultaneous evaluation of ten commonly used physical activity questionnaires. Med Sci Sports (in press).

25 Cooper C, Wickham C, Coggon D. Sedentary occupation in middle life and later risk of fracture of the proximal femur $\mathrm{Br}$ F Ind Med 1990; 47: 69-70.

26 Laporte RE, Montoge HJ, Caspersen C. Assessment of physical activity in epidemiologic research: problems and prospects. Public Health Rep 1985; 100: 131-46.

27 Astrom J, Ahnqvist S, Beertema J, Jonsson B. Physical activity in women sustaining fracture of the neck of the femur. F Bone Foint Surg 1987; 69B: 381-3.

28 Frazer GE. Preventive cardiology. Oxford: Oxford University Press, 1986.

29 Rodgers B. Behaviour and personality in childhood as predictors of adult psychiatric disorder. $\mathcal{F}$ Child Psychol Psychiatry 1990; 31: 393-414.

30 Kuh D, Wadsworth MEJ. Parental height, childhood environment and subsequent adult height in a national birth cohort. Int f Epidemiol 1989; 18: 663-8.

31 Kiernan KE, Colley JRT, Douglas JWB, Reid DD. Chronic cough in young adults in relation to smoking habits, cough in young adults in relation to smoking habits, 3: $236-44$.

32 Dishman RK, Sallis JF, Orenstein DR. The determininants of physical activity and exercise. Public Health Rep 1985;

33 Fenner N. Leisure, exercise and work. In: Cox BD, Blaxte M, Buckle AJ, Fenner NP, Huppert FA, Whichelow M, eds. The Health and Lifestyle Survey. London: Health Promotion Trust, 1987

34 Office of Population Censuses and Surveys. General Household Survey. London: HMSO, 1986.

35 Armstrong N, Balding J, Gentle P, Kirby B. Patterns of physical activity among 11 to 16 year old British children. BMF 1990; 301: 203-5.

36 Dalloss HM, Morgan K, Bussey EJ, Ebrahim SBJ, Tentem PH, Arie THD. Levels of customary physical activity among the old and very old living at home. $\mathcal{f}$ Epidemiol Community Health 1988; 42: 121-7. 